\title{
青海湖沙柳河流域不同时期地表水与 地下水的相互作用
}

\author{
雷义珍 ${ }^{1,2}$, 曹生奎 ${ }^{1,2}$, 曹广超 ${ }^{1,2}$, 杨羽帆 ${ }^{1,2}$, \\ 兰 圭 ${ }^{1,2}$, 季雨桐 ${ }^{1,2}$, 李华非 ${ }^{1,2}$
}

(1. 青海师范大学地理科学学院, 西宁 $810008 ; 2$. 青海省自然地理与环境过程重点实验室,西宁 810008)

\begin{abstract}
摘要: 氢氧稳定同位素技术是研究地表水和地下水相互作用的有效手段。依据青海湖沙柳河 流域 2018 年消融期、多雨期和冰冻期所收集的降水、河水和地下水样品中对氢氧同位素组成 $\left(\delta \mathrm{D} 、 \delta^{18} \mathrm{O}\right)$ 的测定结果, 识别和量化不同时期高山草原带和高山草甸带地表水和地下水间的补 给关系和比例, 其目的旨在明确高寒内陆河流域地表水和地下水 $\delta \mathrm{D}$ 和 $\delta^{18} \mathrm{O}$ 受降水影响的时空 差异。结果表明: 青海湖沙柳河流域地表水和地下水 $\delta \mathrm{D}$ 和 $\delta^{18} \mathrm{O}$ 值受降水响应存在时空差异性, $\delta \mathrm{D}$ 和 $\delta^{18} \mathrm{O}$ 值在消融期受降水影响最强, 冰冻期最弱; 在高山草甸带 $\delta \mathrm{D}$ 和 $\delta^{18} \mathrm{O}$ 值受降水的影响强 于高山草原带。消融期的高山草甸带、高山草原带和冰冻期的高山草原带地表水补给地下水 的比例分别为 $80.65 \% 、 93.36 \%$ 和 $89.44 \%$; 多雨期的高山草甸带、高山草原带和冰冻期的高山草 甸带地下水补给地表水的比例分别为 $44.50 \%$ 、 $74.85 \%$ 和 $88.58 \%$ 。研究结果可为该流域水资源 优化配置和管理提供科学依据。
\end{abstract}

关键词：青海湖;沙柳河流域;氢氧稳定同位素;地表水;地下水;相互作用

地表水与地下水间的相互作用是普遍存在的现象，在水资源可持续性管理和保护， 流域尺度生态平衡维持中扮演着重要角色 ${ }^{[1]}$ 。为此, 许多学者研究了它们间的相互作用。 研究热点主要集中在地表水和地下水循环的时空过程 ${ }^{[2-4]}$ 、河床下层的 “底流区” 的水量 和物质能量交换 ${ }^{[5-7]}$ 、不同自然因素和人类活动对河流一含水层水量交换的定量影响评 价 ${ }^{[8-11]}$ 等方面。研究方法主要有直接水量测量、间接实验法和水量平衡法 ${ }^{[12]}$ 。直接水量测 量需要大量观测数据且测得的数据为点数据, 较大尺度数据获取困难 ${ }^{[13]}$; 间接实验法通 过相关的温度观测和热力学方法进行建模推算, 在应用中需要较多假设, 对地表水的变 化响应难以考虑 ${ }^{[14]}$; 水量平衡法中可借助同位素技术确定地表水与地下水交换量, 该方 法灵活, 实际应用广泛 ${ }^{[15-17]}$, 特别适合于地质地貌复杂、缺乏观测资料区域地表水和地下 水的相互作用研究 ${ }^{[18]}$ 。

青海湖处于东亚季风、印度季风和西风带三者的交汇地带，是维系青藏高原生态安 全的重要水体 ${ }^{[19]}$ 。由于深居内陆, 远离太平洋和印度洋, 湿润的东部季风和东南季风为 该区提供的降水和地表径流较少，造成当地牧民生活用水和牲畜用水以地表水和地下水 为主, 尤其在河面封冻的春冬季, 地下水几乎是域内唯一水源。因此, 青海湖流域地下 水和地表水相互作用的研究显得尤为重要。金章东等 ${ }^{[20]}$ 和 Xiao 等 ${ }^{[2]}$ 通过青海湖环湖地区 不同水体氢氧、锶镭同位素和水化学特征组成, 揭示了降水是青海湖流域浅层地下水和

收稿日期：2019-04-20；修订日期：2019-08-22

基金项目：青海省自然科学基金项目（2018-ZJ-905); 青海省 “高端创新人才千人计划” (青人才字 [2016] 11号); 青海省 “135高层次人才培养工程”

作者简介：雷义珍 (1994- ), 男, 重庆巫溪人, 硕士, 研究方向为生态水文与水资源。E-mail: Leiyizhen@163.com 通讯作者：曹生奎（1979-），男，青海大通人，博士，教授，研究方向为生态水文与水资源。

E-mail: caoshengkui@163.com 
河水的主要补给来源; 崔步礼 ${ }^{[22]}$ 发现环湖地下水的补给源为青海湖流域内降水, 补给高 度多在 3400 4000 m 之间; 杨羽帆等 ${ }^{[23]}$ 对青海湖沙柳河流域浅层地下水的氢氧稳定同位 素分布特征进行了分析, 揭示其地下水补排关系。以上研究都表明青海湖流域地下水与 地表水间存在相互作用，但其量化研究还较为薄弱。

沙柳河流域面积仅占青海湖流域的 $1 / 12$ ，而年径流量占青海湖人湖流量的 $1 / 5^{[24]}$ 。而 且沙柳河流域相对比较封闭和完整，植被类型齐全，其流域水文过程很具有代表性，可 基本反映青海湖流域地表水与地下水相互作用。以上特点决定了沙柳河流域成为研究青 海湖流域地表水与地下水相互作用的理想区域。基于此，本文借助氢氧稳定同位素技术 对消融期、多雨期和冰冻期青海湖沙柳河流域地下水和地表水相互作用进行量化研究, 旨在揭示青海湖沙柳河流域不同时期地表水与地下水的混合比例，为该流域水资源的优 化配置和管理提供科学依据。

\section{1 研究方法与数据来源}

\section{1 研究区概况}

研究区（图 1）位于青海湖北部的沙柳河流域，介于 $37^{\circ} 10^{\prime} 55.92^{\prime \prime}$ 37 51'2.16"N、 99³7'10.20" 100²17'9.96"E之间，流域面积 $1679.2 \mathrm{~km}^{2}$ ，河长 $106 \mathrm{~km}$ ，是青海湖流域第 二大河流，2018 年年径流量为 $4.79 \times 10^{8} \mathrm{~m}^{3}$ 。其地层主要由千枚岩片麻岩、志留纪砂岩片 岩、晚古生代石灰岩砂岩和第四纪沉积岩组成 ${ }^{[21]}$ 。千枚岩片麻岩分布在刚察小寺和撒拉 沟支流中游区域，志留纪砂岩片岩分布在流域上游伊克乌兰河流域西南方向，晚古生代 石灰岩砂岩分布最广，集中在刚察大寺、瓦彦曲、伊克乌兰乡等中上游地区，第四纪沉

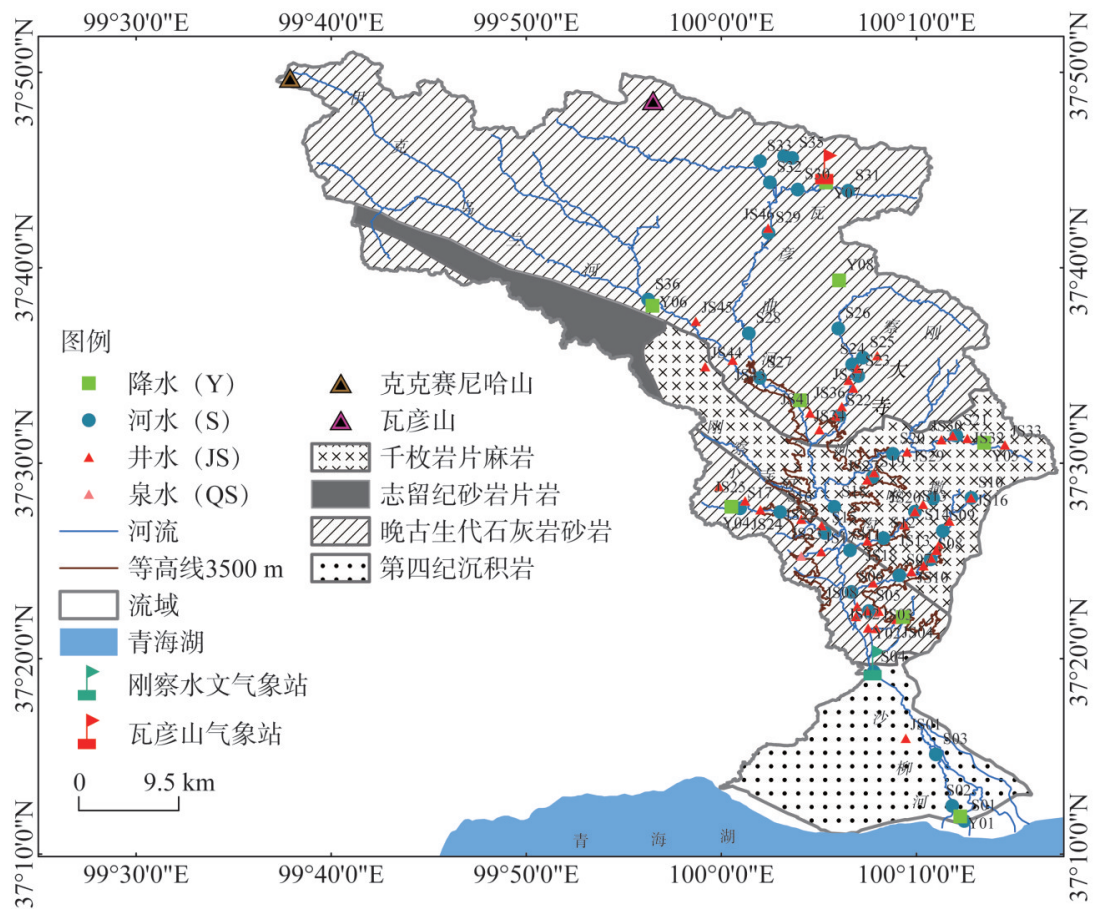

图 1 研究区地层 ${ }^{[2]}$ 和采样点分布

Fig. 1 The stratigraphic distribution and sampling point distribution of the Shaliu River Basin 
积岩分布在下游湖积平原地区。地层类型和海拔高度决定沙柳河地下水的发育形势及埋 深。上游分布着大范围的石灰岩砂岩, 使地下水埋深较深, 以基岩裂隙水为主; 中游也分 布着石灰岩砂岩，但受上游地下水补给，地下水以潜水为主，埋深较深; 下游有第四纪沉 积岩，加之上中游地下水补给作用，地下水埋深较浅，以层间承压水为主（图 1） ${ }^{[25]}$ 。

其流域受东亚季风、西风交替控制，属高原大陆性气候 ${ }^{[25]}$ 。研究区土壤植被类型较 多, 随海拔表现出明显的分级现象。海拔 $4150 \mathrm{~m}$ 以上的地区, 植被覆盖度低, 土壤以高 山寒漠土为主； 3700 4150 m 的地区，植被多为高山嵪草（Kobresia pygmaea）和矮高草 (Kobresia humilis), 土壤多为高山草甸土; 3400 3700 m 的地区, 植物以嵩草 (Kobresia spp.）和风毛菊（Saussurea superba）为主，土壤以山地草甸土为主；3200 3400 m 的 地区，植物多为苃芨草（Achnatherum splendens）、冰草（Agropyron cristatum）和苔草 (Carex spp.), 土壤主要为栗钙土 ${ }^{[25]}$ 。因此, 根据流域地层、土壤和植被分布, 将研究区 分为高山荒漠、高山草甸和高山草原三个地带。在高山荒漠带，植被覆盖度低，土壤以 寒漠土为主, 地层透水性好, 海拔范围为 $4100 \mathrm{~m}$ 以上; 在高山草甸带, 植被以嵩草为 主, 土壤主要为草甸土, 地层透水性较好, 海拔范围为 3500 3800 m; 在高山草原带, 植被主要为苃芨草，土壤以栗钻土为主，地层透水性差，海拔范围为 3200 3500 m。

\section{2 数据来源和分析方法}

\subsection{1 样品采集和数据获取}

如前所述，本文将研究区分为高山荒漠带、高山草甸带和高山草原带进行样品采 集，但野外实际采样时发现，高山荒漠带地下水样品采集难度大。因此将研究区分为高 山草原带和高山草甸带来进行样品采集和数据分析。各水体采样点分布如图 1 所示。降 水为雨水，样点固定分布在沙柳河干流上中下游和各支流上游，共计 8 处; 地表水为河 水, 采样点固定分布遵从主干河流海拔下降 $100 \mathrm{~m}$ 采集 1 处、支流河水样品点均匀分布 的原则，共 36 处; 地下水为井水和泉水，固定采样点集中分布在沙柳河下游干流及支流 两侧，共46处。

样品分别定点采集于 2018 年 4 月、 8 月和 11 月，具体时间为 4 月 22-24 日、8月 25-28 日和 11 月 23-26日。4 月为消融期, 土壤开始解冻和上游冰雪融化, 致使河水流量逐渐增 加; 8 月为多雨期, 研究区降水较多, 径流量较大; 11 月为冰冻期, 气温降低、河水结 冰和土壤封冻使得流量较小，以基流为主。

采集样品时因道路冰冻和道路崎岖, 造成一些样点的样品缺失。研究周期内共采集 了 21 组降水, 105 组地表水, 126 组地下水（表 1), 其中 6 个样点降水、33 个样点地表水 和 40 个样点地下水在三个时期内都是齐全的。降水利用自制式防蒸发式集雨筒（5 L, 均匀分布在流域内）收集各时期内的多次混合降水，收集前倒人 $1 \mathrm{~cm}$ 厚矿物油层来防止 蒸发, 收集时利用带有 $0.22 \mu \mathrm{m}$ 滤膜的注射器进行过滤。地表水样品为河水, 河水采集 于离河岸 1 2 $\mathrm{m}$ 、水面以下 $0.2 \mathrm{~m}$ 的流动河水; 地下水为井水和泉水, 井水用水洜抽取 15 30 分钟后采集, 泉水在露头处采集。所有水样都是 2 份装样于事先用超纯水清洗过 的 $60 \mathrm{~mL}$ 高密度聚乙烯塑料瓶（HDPE）中, 并用Parafilm 膜作密封处理, 带回实验室置 于 $-4{ }^{\circ} \mathrm{C}$ 的环境中冷冻, 以备于氢氧稳定同位素组成测定。

大气温度和降水量数据由瓦彦山（又称瓦颜山）自动气象站和刚察县气象站监测数据 (来自青海省气象局) 获取（图 1); 沙柳河水文站径流数据来自青海省水文水资源勘测局。

\subsection{2 样品测定}

氢氧稳定同位素组成 $\left(\delta \mathrm{D}\right.$ 和 $\left.\delta^{18} \mathrm{O}\right)$ 利用青海师范大学青海省自然地理与环境过程重 
点实验室的 LGR 公司液态水同位素分析仪（Model：912 0026 0001）进行测定，D和 ${ }^{18} \mathrm{O}$ 同位素比值 $(\delta)$ 通常参照维也纳标准海水 $(\mathrm{V}-\mathrm{SMOW})$ 以每千分位 $(\%)$ 表示:

$$
\delta_{\text {样品 }}=\left(R_{\text {样品 }} / R_{\text {标准洋品 }}-1\right) \times 1000
$$

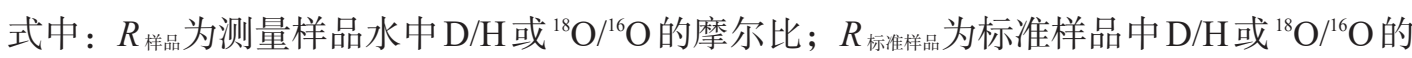
摩尔比。标准样品采用国际公认的维也纳标准平均海水 (Vienna Standard Mean Ocean Water, V-SMOW $) 。 \delta \mathrm{D}$ 和 $\delta^{18} \mathrm{O}$ 测定精度分别为 $1 \% 0$ 和 $0.2 \%$ 。本文中氧同位素的测试精度 和准确度比氢同位素高，因而对 $\delta^{18} \mathrm{O}$ 值进行数据分析代表不同时期各水体 $\delta \mathrm{D}$ 和 $\delta^{18} \mathrm{O}$ 值特征。

\subsection{3 数据分析}

本文应用了双组分混合模型 ${ }^{[26]}$ 计算青海湖沙柳河流域不同时期地表水与地下水的混 合比例。该模型有两个关键假设，一是两组分间必须符合线性规律，即混合组分后的示 踪剂浓度应位于混合前两组分示踪剂浓度混合线上 ${ }^{[27]}$; 二是这种线性规律只是水量的混 合 ${ }^{[28]}$ 。一般而言, 氢同位素 (D) 在水分蒸发和循环过程中不太敏感, 不同水体差异较 小; 氧同位素 $\left({ }^{18} \mathrm{O}\right)$ 表现出明显的差异, 且氧同位素的测试精度和准确度比氢同位素 高，因而通常选择 ${ }^{18} \mathrm{O}$ 来估计地表水和地下水的混合比例 ${ }^{[26]}$ 。

当地表水补给地下水时, 补给比例基于下列方程计算 ${ }^{[26]}$ :

$$
\delta^{18} \mathrm{O}_{G}=\delta^{18} \mathrm{O}_{R} \times x+\delta^{18} \mathrm{O}_{P} \times(100-x)
$$

式中： $x$ 是地表水和地下水的混合比例 $(\%) ; \delta^{18} \mathrm{O}_{G}$ 和 $\delta^{18} \mathrm{O}_{R}$ 分别代表地下和地表水 $\delta^{18} \mathrm{O}$ 测试值; $\delta^{18} \mathrm{O}_{P}$ 多次混合降水的 $\delta^{18} \mathrm{O}$ 加权平均值，计算公式为 ${ }^{[24]}$ :

$$
\delta^{18} \mathrm{O}_{P}=\sum_{i=1}^{n}\left(\delta^{18} \mathrm{O}_{i} \times P_{i}\right) / \sum_{i=1}^{n} P_{i}
$$

式中: $P_{i}$ 代表各样点的降水量 $(\mathrm{mm}) ; \delta^{18} \mathrm{O}_{i}$ 代表各样点的多次混合降水测定值。

当地下水补给地表水时, 补给比例则应用式 (4) 进行刻画 ${ }^{[26]}$ :

$$
\delta^{18} \mathrm{O}_{G}=\delta^{18} \mathrm{O}_{R} \times x+\delta^{18} \mathrm{O}_{P} \times(100-x)
$$

利用高斯标准差传播定律对双组分混合模型的不确定性进行评估，可以定量评价示 踪剂信号的分析误差和系统误差 ${ }^{[2]}$ 。 $W$ 为地表水补给地下水的不确定性, 计算公式如下 ${ }^{[29]}$ :

$$
W=\sqrt{\left[W_{R} \frac{\delta^{18} \mathrm{O}_{p}-\delta^{18} \mathrm{O}_{G}}{\left(\delta^{18} \mathrm{O}_{p}-\delta^{18} \mathrm{O}_{R}\right)^{2}}\right]^{2}+\left[W_{p} \frac{\delta^{18} \mathrm{O}_{G}-\delta^{18} \mathrm{O}_{R}}{\left(\delta^{18} \mathrm{O}_{p}-\delta^{18} \mathrm{O}_{R}\right)^{2}}\right]^{2}+\left[W_{G} \frac{-1}{\delta^{18} \mathrm{O}_{p}-\delta^{18} \mathrm{O}_{R}}\right]^{2}}
$$

式中: $\delta^{18} \mathrm{O}_{R}$ 和 $\delta^{18} \mathrm{O}_{G}$ 分别代表地表水 $\delta^{18} \mathrm{O}$ 值和地下水 $\delta^{18} \mathrm{O}$ 值, $\delta^{18} \mathrm{O}_{p}$ 代表降水 $\delta^{18} \mathrm{O}$ 值。 $W_{R} 、 W_{p}$ 和 $W_{G}$ 是上述三种成分的不确定性，分别为其平均值的标准差 (SE)。

当地下水补给地表水时, 不确定性计算方法为 ${ }^{[29]}$ :

$$
W=\sqrt{\left[W_{G} \frac{\delta^{18} \mathrm{O}_{p}-\delta^{18} \mathrm{O}_{R}}{\left(\delta^{18} \mathrm{O}_{p}-\delta^{18} \mathrm{O}_{G}\right)^{2}}\right]^{2}+\left[W_{p} \frac{\delta^{18} \mathrm{O}_{R}-\delta^{18} \mathrm{O}_{G}}{\left(\delta^{18} \mathrm{O}_{p}-\delta^{18} \mathrm{O}_{G}\right)^{2}}\right]^{2}+\left[W_{R} \frac{-1}{\delta^{18} \mathrm{O}_{p}-\delta^{18} \mathrm{O}_{G}}\right]^{2}}
$$

\section{2 结果分析}

\section{1 结果}

\section{1 .1 不同时期气温、降水量和流量变化}

基于刚察气象站和瓦彦山自动气象站监测数据, 青海湖沙柳河流域高山草原带和 高山草甸带2018 年各月月均气温和降水量变化趋势总体一致（图 2a）。1月月均气温在 
全年最低，其值分别为 $-10.8{ }^{\circ} \mathrm{C}$ 和 $-15.8{ }^{\circ} \mathrm{C}$, 该月无降水。1月后气温逐渐升高, 8 月达 到最高, 其值分别为 $13.3{ }^{\circ} \mathrm{C}$ 和 $10.5{ }^{\circ} \mathrm{C} ; 1$ 月开始降水量也逐渐增加, 分别在 7 月 (163.3 mm) 和9月（105.4 mm）达到峰值。此后气温下降、降水减少，但瓦彦山站的 降水量减少较为剧烈（图 2a）。2018 年青海湖沙柳河月流量结果显示（图 2b)，1-4月和 10- 12 月人湖月流量较小，5-9月人湖月流量较大； 2 月人湖流量最小，为 $1.79 \mathrm{~m}^{3} / \mathrm{s} ， 7$ 月流 量最大, 为 $49.3 \mathrm{~m}^{3} / \mathrm{s}$ 。
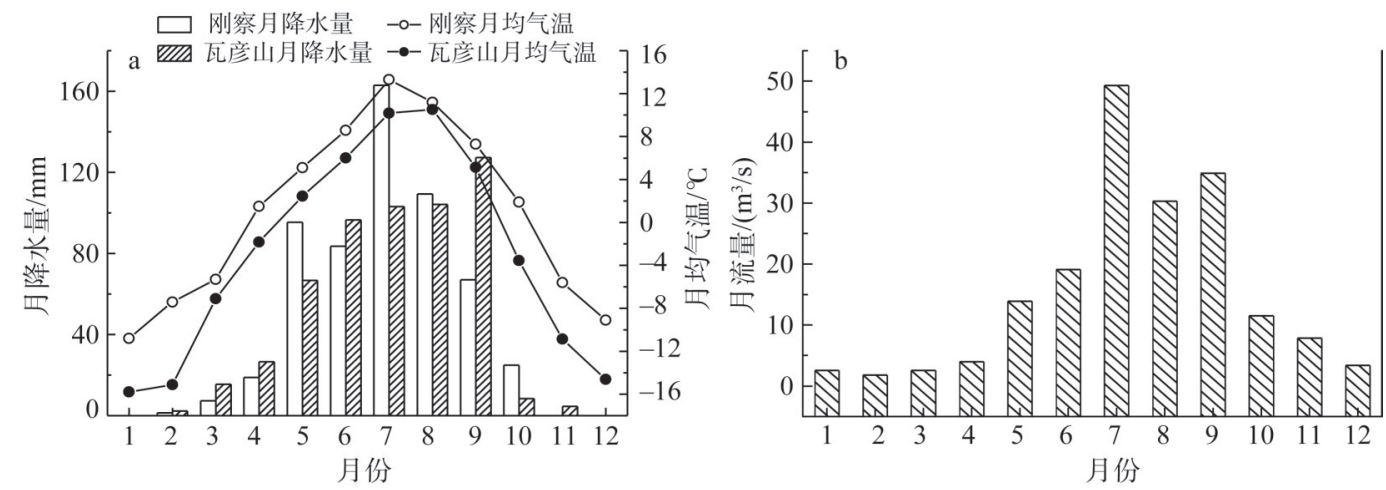

图 22018 年青海湖沙柳河流域月均气温、降水量和流量变化

Fig. 2 The variations of monthly average air temperature, precipitation and runoff in Shaliu River Basin in 2018

\subsection{2 不同时期各水体 $\delta \mathrm{D}$ 和 $\delta^{18} \mathrm{O}$ 值特征}

消融期、多雨期和冰冻期高山草原带和高山草甸带的降水、地表水和地下水氢氧稳 定同位素组成如表 1 和表 2 所示。因 $\delta \mathrm{D}$ 和 $\delta^{18} \mathrm{O}$ 变化大致相同，且 $\delta^{18} \mathrm{O}$ 测试精度较高，故只 作 $\delta^{18} \mathrm{O}$ 值特征描述。三个时期高山草原带的降水 $\delta^{18} \mathrm{O}$ 值分别为 $-10.78 \%$ - 4.30\% 、 $-11.62 \% 0 \sim-9.46 \% 0$ 和 $-18.14 \%$ - 13.79\% ；高山草甸带的降水 $\delta^{18} \mathrm{O}$ 值分别为 $-4.37 \% 0 \sim$ $-3.92 \%$ 、 $-12.79 \%$ - 10.78\% 和-15.38\% - 13.89\%。 。它们均介于以往青海湖降水 $\delta^{18} \mathrm{O}$ 值 $(-24.40 \%$ $-2.8 \% 0)$ 的范围内 ${ }^{[18,30]}$ 。高山草原带河水 $\delta^{18} \mathrm{O}$ 值分别为 $-7.27 \% 0 \sim-5.83 \%$ 、 $-9.63 \% \sim-6.68 \%$ 和 $-8.13 \% 0 \sim-7.02 \%$ ，高山草甸带河水 $\delta^{18} \mathrm{O}$ 值分别为 $-9.47 \% 0 \sim-5.28 \% 0$ 、 $-47 \% \sim-6.74 \%$ 和 $-8.79 \%$ 6.46\% , , 与以往青海流域河水 $\delta^{18} \mathrm{O}$ 值 $(-6.96 \% 0 \sim-8.11 \% 0$ ）差异 不大 ${ }^{[22]}$ 。高山草原带地下水 $\delta^{18} \mathrm{O}$ 值分别为 $-8.26 \%$ - 5.90\%。、-7.86\% - 5.80\%。和-8.34\% $-5.93 \%$; 高山草原带地下水 $\delta^{18} \mathrm{O}$ 值分别为 $-8.26 \% 0 \sim-5.90 \% 0 、-7.86 \%$ $-5.80 \%$ 和 $-8.34 \%$ 。 $\sim-5.93 \%$ ，与 2017 年 7-11 月地下水 $\delta^{18} \mathrm{O}$ 值 $(-8.54 \% 0 \sim-6.02 \% 0)^{[23]}$ 接近。

在高山草原带，消融期、多雨期到冰冻期该流域降水 $\delta^{18} \mathrm{O}$ 均值变小，地下水 $\delta^{18} \mathrm{O}$ 均 值也变小，但变化没有降水明显，河水 $\delta^{18} \mathrm{O}$ 均值先变小后增大（表 1 ）。消融期降水、河 水和地下水 $\delta^{18} \mathrm{O}$ 值大小顺序为河水 $>$ 地下水 $>$ 降水, 多雨期和冰冻期为地下水 $>$ 河水 $>$ 降水 (表1)。

在高山草甸带, 消融期、多雨期到冰冻期该流域降水 $\delta \mathrm{D}$ 和 $\delta^{18} \mathrm{O}$ 均值变小（表 2$)$, 河 水 $\delta \mathrm{D}$ 和 $\delta^{18} \mathrm{O}$ 均值先变小后增大, 地下水 $\delta \mathrm{D}$ 和 $\delta^{18} \mathrm{O}$ 均值先变大后变小 (表 2$)$ 。消融期降 水、河水和地下水 $\delta \mathrm{D}$ 和 $\delta^{18} \mathrm{O}$ 值大小顺序为降水 $>$ 地下水 $>$ 河水, 多雨期和冰冻期为地下水 $>$ 河水>降水（表 2 )。

\subsection{3 不同时期各水体 $\delta \mathrm{D}$ 和 $\delta^{18} \mathrm{O}$ 值的关系}

不同时期青海湖沙柳河流域不同水体 $\delta \mathrm{D}$ 和 $\delta^{18} \mathrm{O}$ 值间的相关关系结果显示（图 3 ），在 


\section{表 1 不同时期青海湖沙柳河流域高山草原带各水体 $\delta \mathrm{D}$ 和 $\delta^{18} \mathrm{O}$ 值}

Table 1 The $\delta \mathrm{D}$ and $\delta^{18} \mathrm{O}$ values of different water bodies of alpine steppe zone in Shaliu River Basin in different periods

\begin{tabular}{|c|c|c|c|c|c|c|c|c|}
\hline \multirow{2}{*}{ 水体 } & \multirow{2}{*}{ 月份 } & \multirow{2}{*}{$n$} & \multicolumn{3}{|c|}{$\delta \mathrm{D} / \% 0$} & \multicolumn{3}{|c|}{$\delta^{18} \mathrm{O} / \%$} \\
\hline & & & $\min$ & mean/SE & $\max$ & $\min$ & mean/SE & $\max$ \\
\hline \multirow[t]{3}{*}{ 降水 } & 4月 & 4 & -64.40 & $-37.94 / 23.10$ & -8.84 & -10.78 & $-6.96 / 2.73$ & -4.30 \\
\hline & 8月 & 5 & -77.34 & $-69.95 / 7.36$ & -59.46 & -11.62 & $-10.52 / 0.91$ & -9.46 \\
\hline & 11 月 & 5 & -129.59 & $-100.59 / 17.00$ & -87.41 & -18.14 & $-15.13 / 1.75$ & -13.79 \\
\hline \multirow[t]{3}{*}{ 河水 } & 4月 & 12 & -43.59 & $-37.85 / 3.02$ & -34.67 & -7.27 & $-6.34 / 0.45$ & -5.83 \\
\hline & 8 月 & 15 & -54.80 & $-45.12 / 3.99$ & -40.36 & -9.63 & $-8.78 / 0.60$ & -6.68 \\
\hline & 11月 & 14 & -48.96 & $-44.03 / 2.20$ & -41.52 & -8.13 & $-7.46 / 038$ & -7.02 \\
\hline \multirow[t]{3}{*}{ 地下水 } & 4月 & 21 & -45.30 & $-39.70 / 4.43$ & -23.91 & -7.15 & $-6.46 / 0.49$ & -5.07 \\
\hline & 8 月 & 23 & -50.34 & $-40.93 / 3.31$ & -36.68 & -7.96 & $-6.61 / 0.48$ & -5.84 \\
\hline & 11 月 & 25 & -55.53 & $-45.83 / 5.37$ & -36.18 & -10.21 & $-8.27 / 1.47$ & -6.07 \\
\hline
\end{tabular}

注： $\min$ 、 $\operatorname{mean} / \mathrm{SE}$ 和 $\max$ 分别代表最小值、平均值/标准误差和最大值，下同。

表 2 不同时期青海湖沙柳河流域高山草甸带各水体 $\delta \mathrm{D}$ 和 $\delta^{18} \mathrm{O}$ 值

Table 2 The $\delta \mathrm{D}$ and $\delta^{18} \mathrm{O}$ values of different water bodies of alpine meadow zone in Shaliu River Basin in different periods

\begin{tabular}{|c|c|c|c|c|c|c|c|c|}
\hline \multirow{2}{*}{ 水体 } & \multirow{2}{*}{ 月份 } & \multirow{2}{*}{$n$} & \multicolumn{3}{|c|}{$\delta \mathrm{D} / \%$} & \multicolumn{3}{|c|}{$\delta^{18} \mathrm{O} / \% 0$} \\
\hline & & & $\min$ & mean/SE & $\max$ & $\min$ & mean/SE & $\max$ \\
\hline \multirow[t]{3}{*}{ 降水 } & 4月 & 2 & -18.21 & $-13.84 / 6.19$ & -9.46 & -4.37 & $-4.15 / 0.32$ & -3.92 \\
\hline & 8月 & 3 & -81.83 & $-76.18 / 6.31$ & -69.36 & -12.79 & $-11.60 / 1.06$ & -10.78 \\
\hline & 11月 & 2 & -100.31 & $-95.01 / 7.50$ & -89.70 & -15.38 & $-14.64 / 1.06$ & -13.89 \\
\hline \multirow[t]{3}{*}{ 河水 } & 4月 & 22 & -59.37 & $-41.86 / 6.35$ & -26.78 & -9.47 & $-7.01 / 1.27$ & -5.28 \\
\hline & 8月 & 21 & -57.06 & $-48.10 / 4.04$ & -40.12 & -9.47 & $-7.88 / 0.81$ & -6.74 \\
\hline & 11月 & 21 & -53.15 & $-46.87 / 4.00$ & -35.30 & -8.79 & $-7.97 / 0.71$ & -6.46 \\
\hline \multirow[t]{3}{*}{ 地下水 } & 4月 & 19 & -50.38 & $-41.09 / 4.29$ & -34.37 & -8.26 & $-6.82 / 0.69$ & -5.90 \\
\hline & 8月 & 18 & -47.71 & $-40.54 / 3.85$ & -33.86 & -7.86 & $-6.63 / 0.63$ & -5.80 \\
\hline & 11月 & 20 & -51.11 & $-42.66 / 4.53$ & -35.83 & -8.34 & $-7.11 / 0.70$ & -5.93 \\
\hline
\end{tabular}

高山草原带，消融期河水和地下水 $\delta \mathrm{D}$ 和 $\delta^{18} \mathrm{O}$ 值分布在局地降水线（LMWL）左上方，地 下水 $\delta \mathrm{D}$ 和 $\delta^{18} \mathrm{O}$ 值和河水 $\delta \mathrm{D}$ 和 $\delta^{18} \mathrm{O}$ 值交错分布（图 3a）; 多雨期河水和地下水 $\delta \mathrm{D}$ 和 $\delta^{18} \mathrm{O}$ 值 位于局地降水线（LMWL）右上方，且地下水、河水和降水 $\delta \mathrm{D}$ 和 $\delta^{18} \mathrm{O}$ 值存在分离现象， 地下水 $\delta \mathrm{D}$ 和 $\delta^{18} \mathrm{O}$ 值最大，河水 $\delta \mathrm{D}$ 和 $\delta^{18} \mathrm{O}$ 值次之，降水 $\delta \mathrm{D}$ 和 $\delta^{18} \mathrm{O}$ 值最小（图 $3 \mathrm{~b}$ ）；冰冻期 河水和地下水 $\delta \mathrm{D}$ 和 $\delta^{18} \mathrm{O}$ 值位于局地降水线（LMWL）右上方，且河水和地下水 $\delta \mathrm{D}$ 和 $\delta^{18} \mathrm{O}$ 值与降水 $\delta \mathrm{D}$ 和 $\delta^{18} \mathrm{O}$ 值之间的差异较多雨期增大，河水 $\delta \mathrm{D}$ 和 $\delta^{18} \mathrm{O}$ 值位于地下水线（GWL） 右下方（图 3c)。

在高山草甸带，消融期河水和地下水 $\delta \mathrm{D}$ 和 $\delta^{18} \mathrm{O}$ 值分布在局地降水线（LMWL）两 侧，河水和地下水 $\delta \mathrm{D}$ 和 $\delta^{18} \mathrm{O}$ 值交错分布，但河水离散程度比地下水大（图 3a）; 多雨期 降水、河水和地下水 $\delta \mathrm{D}$ 和 $\delta^{18} \mathrm{O}$ 值与高山草原带多雨期相似，降水与河水和地下水存在分 离现象, 地下水 $\delta \mathrm{D}$ 和 $\delta^{18} \mathrm{O}$ 值最大, 河水 $\delta \mathrm{D}$ 和 $\delta^{18} \mathrm{O}$ 值次之, 降水 $\delta \mathrm{D}$ 和 $\delta^{18} \mathrm{O}$ 值最小（图 3b); 冰冻期河水和地下水 $\delta \mathrm{D}$ 和 $\delta^{18} \mathrm{O}$ 值分布在局地降水线 ( $\mathrm{LMWL}$ ) 右下侧, 河水 $\delta \mathrm{D}$ 和 $\delta^{18} \mathrm{O}$ 值位 于地下水线（GWL）右上方（图3c）。 

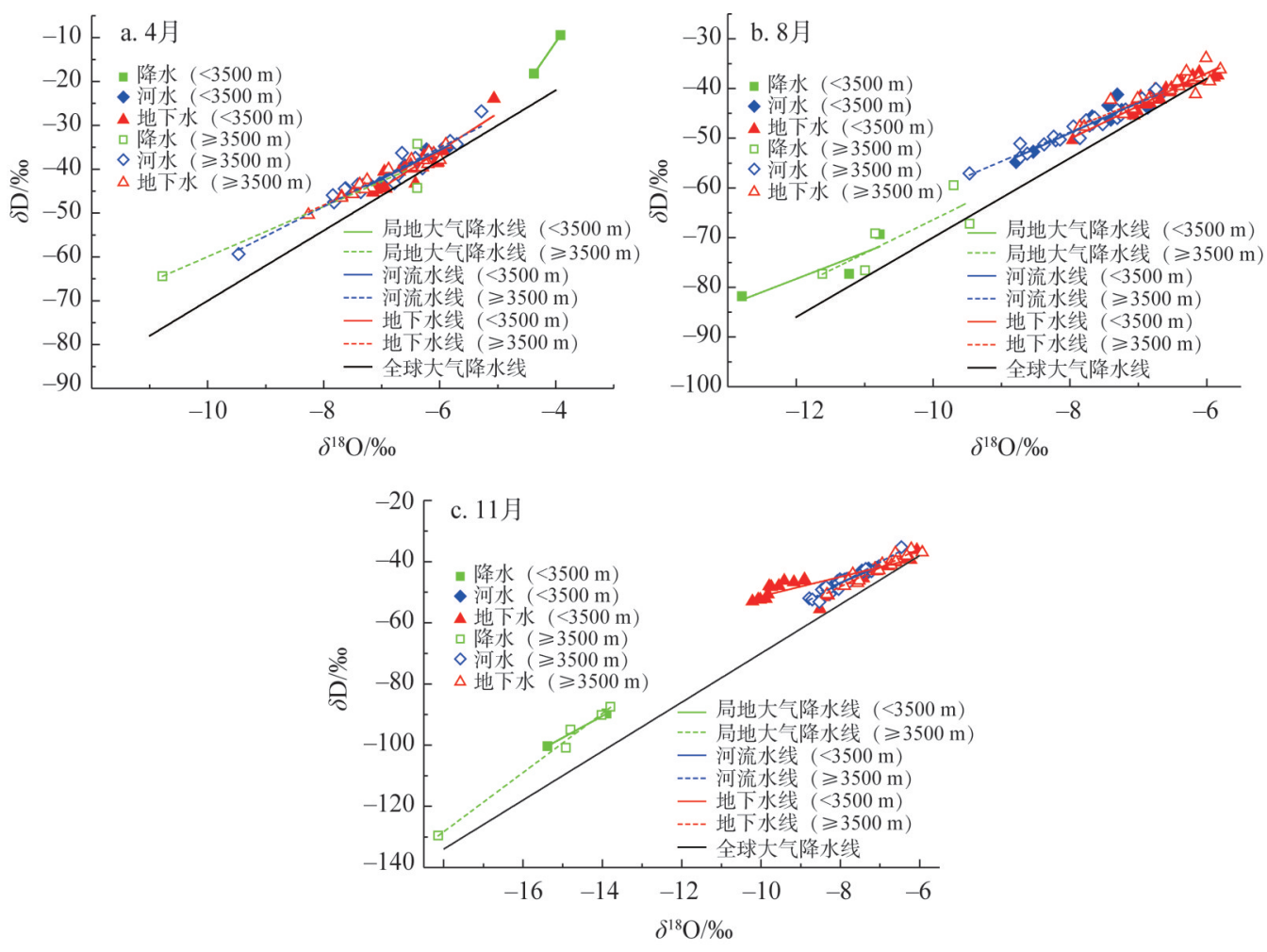

图 3 不同时期青海湖沙柳河流域各水体 $\delta \mathrm{D}$ 和 $\delta^{18} \mathrm{O}$ 值间的相关关系

Fig. 3 The relationships between $\delta \mathrm{D}$ and $\delta^{18} \mathrm{O}$ of different water bodies in Shaliu River Basin in different periods

\section{2 分析}

\section{2 .1 地表水和地下水氢氧稳定同位素组成对降水的响应}

降水是青海湖流域内水分的唯一输人源 ${ }^{[18]}$, 故青海湖沙柳河流域地表水和地下水氢 氧稳定同位素组成会受降水影响。根据 $\delta \mathrm{D}$ 和 $\delta^{18} \mathrm{O}$ 关系图可得, 在消融期, 高山草甸带地 表水和地下水散布在降水周围，而高山草原带地表水和地下水位于降水左上侧（图 3a）, 表明该时期高山草甸带地表水和地下水受到降水的影响比高山草原带大，这可能与地下 水和地表水的补给源自上游有关 ${ }^{[22]}$; 在多雨期, 高山草原带和高山草甸带地表水和地下 水都位于降水右上侧（图 3b)，表明该时期两个区域地表水和地下水受降水氢氧稳定同 位素组成影响差异不大；在冰冻期，高山草原带和高山草甸带地表水和地下水同样位于 降水右上侧（图 3c），但冰冻期较多雨期偏离程度大，这表明冰冻期地表水和地下水对降 水氢氧稳定同位素组成响应弱于冰冻期。综上, 地表水和地下水受降水氢氧稳定同位素 组成影响大小时间上依次为消融期 $>$ 多雨期 $>$ 冰冻期，空间上为高山草甸带 $>$ 高山草原 带。因此, 消融期、多雨期到冰冻期地表水和地下水 $\delta \mathrm{D}$ 和 $\delta^{18} \mathrm{O}$ 均值变化比降水小，是由 地表水和地下水氢氧稳定同位素组成受降水影响强度减弱造成的。

\section{2 .2 地表水和地下水补给关系}

应用双组分混合模型计算地表水和地下水相互作用时，关键假设为混合组分后的示 踪剂浓度应位于混合前两组分示踪剂浓度混合线上 ${ }^{[28]}$, 因而根据降水、地表水和地下水 氢氧稳定同位素组成的线性关系识别地表水和地下水补给机制。

在消融期，高山草原带和高山草甸带地下水氢氧稳定同位素组成介于降水和河水之 
间（图 4a），表明该时期两个区域均为地表水补给地下水。在多雨期，高山草原带和高山 草甸带地表水氢氧稳定同位素组成介于降水和地下水之间（图 4b)，表明多雨期两个区 域均为地下水补给地表水。在冰冻期, 高山草甸带的地下水氢氧稳定同位素组成介于降 水和地表水之间（图 4a），而高山草甸带地表水氢氧稳定同位素组成介于降水和地下水之 间（图 4b），表明冰冻期高山草原带地表水补给地下水，而高山草原带地下水补给地表 水。上述研究结果与以往研究结果一致, 降水是青海湖流域地表水和浅层地下水的主要 补给来源 ${ }^{[2,21,23]}$ ，在此基础上，本文还深人探讨了不同时期区域的地表水和地下水补给关系。
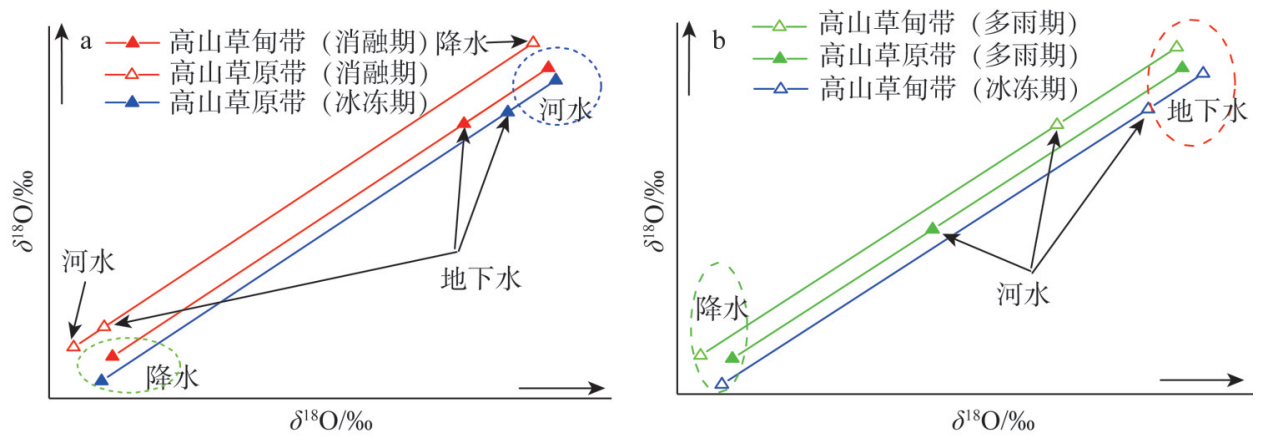

图 4 不同时期青海湖沙柳河流域地表水与地下水补给关系

Fig. 4 The relationships of recharge between surface water and groundwater in Shaliu River Basin in different periods

\section{2 .3 地表水和地下水的相互补给比例}

由上可得，地下水与地表水相互作用存在两种，一是地表水补给地下水，如消融期 高山草原带、高山草甸带和冰冻期高山草原带地下水受到了地表水的补给，其比例分别 为 $80.65 \%$ 、93.36\% 和 89.44\%（表 3)，二是地下水补给地表水，如多雨期高山草原带、 高山草甸带和冰冻期高山草甸带地表水受到了地下水的补给，其补给比例相应为 $44.50 \%$ 、74.85\%和 $88.58 \%$ （表 3 ）。

消融期高山草原带和高山草甸带地表水补给地下水的比例较大，这是由于消融期冰 雪消融和土壤解冻，造成以冰雪形式储存在域内的水分能够透过土壤补给地下水; 冰冻 期高山草原带地表水补给地下水比例高达 $89.44 \%$ ，这可能与中上游高山草甸带地表封 冻，阻隔了下游高山草原带地下水受上游补给的路径，这需要加强地下水和地表水补给 路径和方式研究。多雨期高山草原带和高山草甸带地下水补给地表水，原因可能是多雨 期植被覆盖度高，水分拦截率高，使得降水被土壤吸收后补给地下水，地下水水位升高

表 3 地表水与地下水相互补给比例

Table 3 The proportions of recharge between surface water and groundwater

\begin{tabular}{|c|c|c|c|c|c|}
\hline \multirow{2}{*}{ 时期 } & \multirow{2}{*}{ 区域 } & \multicolumn{2}{|c|}{ 地表水补给地下水 } & \multicolumn{2}{|c|}{ 地下水补给地表水 } \\
\hline & & 比例 & 不确定性 & 比例 & 不确定性 \\
\hline \multirow[t]{2}{*}{ 消融期 } & 高山草原带 & 80.65 & 24.29 & - & - \\
\hline & 高山草甸带 & 93.36 & 130.14 & - & - \\
\hline \multirow[t]{2}{*}{ 多雨期 } & 高山草原带 & - & - & 44.50 & 19.61 \\
\hline & 高山草甸带 & - & - & 74.85 & 18.50 \\
\hline \multirow[t]{2}{*}{ 冰冻期 } & 高山草原带 & 89.44 & 16.09 & - & - \\
\hline & 高山草甸带 & - & - & 88.58 & 24.07 \\
\hline
\end{tabular}


溢出补给地表水。中上游高山草甸带地表水受地下水的补给比例大于下游高山草原带，这 表明两个区域补给方式存在差异，这与杨羽帆等 ${ }^{[23]}$ 对青海湖沙柳河流域地表水和地下水间 补给方式的研究结果一致。冰冻期高山草甸带地表水地下水相互作用为地下水补给地表 水，这是因为地表和河面封冻，降水以雪为主，无法补给地表径流，只能靠地下水补给。

根据高斯标准差传播定律计算出的各时期各区域地表水和地下水相互作用不确定性 如表 3 所示。消融期高山草原带和高山草甸带、多雨期高山草原带和高山草甸带及冰冻 期高山草原带和高山草甸带不确定性分别为 24.29\%和 $130.14 \%$ 、19.61\% 和 18.50\% 及 $16.09 \%$ 和 $24.07 \%$ （表 3）。消融期高山草甸带地表水和地下水相互作用不确定性较其他时 期和区域差异很大，这可能是该时期降水样品缺失造成的，使得该时期降水 $\delta^{18} \mathrm{O}$ 的标准 差 $(2.73 \%$ ）比其他时期大，故需增加降水分辨率的精度。此外，由于消融期的降水样 品个数较少和双组分混合模型假设地表水和地下水相互作用过程中不存在蒸发等其他因 素干扰，使得地表水和地下水相互作用量化结果与实际情况有所偏差。后期研究中将进 一步完善数据和优化模型，以便更准确地量化地表水和地下水相互作用。

\section{3 结论与讨论}

本文基于青海湖沙柳河流域 2018 年消融期、多雨期和冰冻期所收集的降水、河水和 地下水样品，借助氢氧稳定同位素技术，应用双组分混合模型确定研究区的上中下游不 同时期的补给关系和补给比例, 主要获得以下结论:

（1）青海湖沙柳河流域三个时期地表水和地下水氢氧稳定同位素组成对降水的响应存 在时空差异。其时间差异为消融期 $>$ 多雨期 $>$ 冰冻期，空间差异为高山草甸带 $>$ 高山草原带。

（2）基于降水、地表水和地下水氢氧稳定同位素组成的线性关系和双组分混合模 型，获得消融期高山草甸带、高山草原带和冰冻期高山草原带为地表水补给地下水，比 例分别为 $80.65 \%$ 、93.36\% 和 $89.44 \%$, 多雨期高山草甸带、高山草原带和冰冻期高山草甸 带地下水补给地表水，比例分别为 $44.50 \%$ 、74.85\%和 $88.58 \%$ 。

本文量化出青海湖沙柳河流域不同时期地表水与地下水相互作用，验证了氢氧稳定 同位素技术在研究区的应用是科学有效的。同时，本文研究结果可为流域内不同时期不 同地带水资源优化配置提供依据，消融期高山草甸带和高山草原带及冰冻期高山草原带 农牧业生产和居民生活水资源利用应以地下水为主，多雨期高山草甸带和高山草原带及 冰冻期高山草甸带农牧业生产和居民生活水资源利用则应以地表水为主。

\section{参考文献(References):}

[1] PRADA S, CRUZ V J, FIGUEIRA C. Using stable isotopes to characterize groundwater recharge sources in the volcanic island of Madeira, Portugal. Journal of Hydrology, 2016, 536: 409-425.

[2] WOESSNER W W. Stream and fluvial plain ground water interactions: Rescaling hydrogeologic thought. Ground Water, 2000, 38(3): 423-429.

[3] HARVEY J W, NEWLIN J T, KRUPA S L. Modeling decadal timescale interactions between surface water and ground water in the Central Everglades, Florida, USA. Journal of Hydrology, 2006, 320(3): 400-420.

[4] WINTER T C. Relation of streams, lakes, and wetlands to groundwater flow systems. Hydrogeology Journal, 1999, 7(1): $28-45$.

[5] RESTREPO J I, MONTOYA A M, OBEVSEKERA J. A wetland simulation module for the MODFLOW ground water model. Ground Water, 1998, 36(5): 764-770.

[6] OSMAN Y Z, BRUEN M P. Modelling stream-aquifer seepage in an alluvial aquifer: An improved loosing-stream pack- 
age for modflow. Journal of Hydrology, 2002, 264(1): 69-86.

[7] KALBUS E, SCHMIDT C, MOLSON J W, et al. Influence of aquifer and streambed heterogeneity on the distribution of groundwater discharge. Hydrology and Earth System Sciences, 2009, 13(1): 69-77.

[8] CARDENAS M B, WILSON J L, ZLONTNIK V A. Impact of heterogeneity, bed forms, and stream curvature on subchannel hyporheic exchange. Water Resources Research, 2004, 40(8): W08307, Doi: 10.1029/2004wr003008.

[9] CARDENAS M B. Stream-aquifer interactions and hyporheic exchange in gaining and losing sinuous streams. Water Resources Research, 2009, 45(6): W06429, Doi: 10.1029/2008wr007651.

[10] DERX J, BLASCHKE A P, BLOSCHL G. Three-dimensional flow patterns at the river-aquifer interface: A case study at the Danube. Advances in Water Resources, 2010, 33(11): 1375-1387.

[11] WANG G X, YANG L Y, CHEN L, et al. Impacts of land use changes on groundwater resources in the Heihe River Basin. Journal of Geographical Sciences, 2005, 15(4): 405-414.

[12] 朱金峰, 刘悦忆, 章树安, 等. 地表水与地下水相互作用研究进展. 中国环境科学, 2017, 37(8): 3002-3010. [ZHU J F, LIU Y Y, ZHANG S A, et al. Review on the research of surface water and groundwater interactions. China Environmental Science, 2017, 37(8): 3002-3010.]

[13] KALBUS E, RENINSTORF F, SCHIRMER M. Measuring methods for groundwater-surface water interactions: A review. Hydrology and Earth System Sciences, 2006, 10(6): 873-887.

[14] SCHMIDT C, BAYER-RAICH M, SCHINMER M. Characterization of spatial heterogeneity of groundwater-stream water interactions using multiple depth streambed temperature measurements at the reach scale. Hydrology and Earth System Sciences Discussions, 2006, 3(4): 1419-1446.

[15] 姚天次, 章新平, 李广, 等. 湘江流域岳麓山周边地区不同水体中氢氧稳定同位素特征及相互关系. 自然资源学报, 2016, 31(7): 1198-1210. [YAO T C, ZHANG X P, LI G, et al. Characteristics of the stable isotopes in different water bodies and relationships in surrounding areas of Yuelu Mountain in the Xiangjiang River Basin. Journal of Natural Resources, 2016, 31(7): 1198-1210.]

[16] ZHAO D, WANG G C, LIAO F, et al. Groundwater-surface water interactions derived by hydrochemical and isotopic (222Rn, deuterium, oxygen-18) tracers in the Nomhon Area, Qaidam Basin, NW China. Journal of Hydrology, 2018, 565: 650-661.

[17] 谷洪彪, 迟宝明, 王贺, 等. 柳江盆地地表水与地下水转化关系的氢氧稳定同位素和水化学证据. 地理科学进展, 2017, 32(8): 788-789. [GU H B, CHI B M, WANG H, et al. Relationship between surface water and groundwater in the Liujiang Basin hydrochemical constrains. Progress in Geography, 2017, 32(8): 789-799.]

[18] CUI B L, LI X Y. Stable isotopes reveal sources of precipitation in the Qinghai Lake Basin of the Northeastern Tibetan Plateau. Science of the Total Environment, 2015, 527-528: 26-37.

[19] 曹生奎, 陈克龙, 曹广超, 等. 青海湖流域矮高草草甸土壤有机碳密度分布特征. 生态学报, 2014, 34(2): 482-490. [CAO S K, CHEN K L, CAO G C, et al. Characteristics of soil carbon density distribution of the Kobresia humilis meadow in the Qinghai Lake Basin. Acta Ecologica Sinica, 2014, 34(2): 482-490.]

[20] 金章东, 石岳威, 张飞. 青海湖流域浅层地下水补给来源及其位变化. 地球环境学报, 2010, 1(3): 169-174. [JIN Z D, SHI Y W, ZHANG F. Sources of shallow groundwater recharge and changes of water level in Qinghai Lake Basin. Journal of Earth Environment, 2010, 1(3): 169-174.]

[21] XIAO J, JIN Z D, ZHANG F. Geochemical and isotopic characteristics of shallow groundwater within the Lake Qinghai Catchment, NE Tibetan Plateau. Quaternary International, 2013, 313-314: 62-67.

[22] 崔步礼. 基于氢氧稳定同位素的青海湖流域水循环及水量转换关系研究. 北京: 北京师范大学, 2011: 16-18. [CUI B L. Study on the relationship between water cycle and water quantity conversion in Qinghai Lake Basin based on hydrogen and oxygen stable isotope. Beijing: Beijing Normal University, 2011: 16-18.]

[23] 杨羽帆, 曹生奎, 冯起, 等. 青海湖沙柳河流域浅层地下水氢氧稳定同位素分布特征. 中国沙漠, 2019, (5): 1-9. [YANG Y F, CAO S K, FENG Q, et al. Spatial distribution characteristics of composition of stable hydrogen and oxygen isotopes of shallow groundwater in Shaliu River Basin of Qinghai Lake. Journal of Desert Research, 2019, (5): 1-9.]

[24] CUI B L, LI X Y. Runoff processes in the Qinghai Lake Basin, Northeast Qinghai-Tibet Plateau, China: Insights from stable isotope and hydrochemistry. Quaternary International, 2015, 380-381: 123-132.

[25] 刚察县志编纂委员会. 刚察县志. 西安: 陕西人民出版社, 1998: 95-97. [Gangcha County Annals Compilation Committee. Gangcha County. Xi'an: Shaanxi People's Publishing House, 1998: 95-97.] 
[26] GUO Q L, YANG Y S, HAN Y Y, et al. Assessment of surface-groundwater interactions using hydrochemical and isotopictechniques in a coalmine watershed, NW China. Environmental Earth Sciences, 2019, 3: 78-91.

[27] TAN H B, LIU Z H, RAO W B, et al. Stable isotopes of soil water: Implications for soil water and shallow groundwater recharge in hill and gully regions of the Loess Plateau, China. Agriculture, Ecosystems and Environment, 2017, 243: 1-9.

[28] 顾慰祖. 同位素水文学. 北京: 科学出版社, 2011: 145-147. [GU W Z. Isotope Hydrology. Beijing: Science Press, 2011: 145-147.]

[29] WANG W, WU T, ZHAO L, et al. Exploring the ground ice recharge near permafrost table on the Central Qinghai-Tibet Plateau using chemical and isotopic data. Journal of Hydrology, 2018, 560: 220-229.

[30] 吴华武, 李小雁, 赵国琴, 等. 青海湖流域降水和河水中青海湖流域降水和河中 $\delta^{18} \mathrm{O}$ 和 $\delta \mathrm{D}$ 变化特征. 自然资源学报, 2014, 29(9): 1552-1564. [WU H W, LI X Y, ZHAO G Q, et al. Variation characteristics of $\delta^{18} \mathrm{O}$ and $\delta \mathrm{D}$ in precipitation and river water of Qinghai Lake Basin. Journal of Natural Resources, 2014, 29(9): 1552-1564.]

\title{
Study on surface water and groundwater interaction of Shaliu River Basin in Qinghai Lake in different periods
}

\author{
LEI Yi-zhen ${ }^{1,2}$, CAO Sheng-kui ${ }^{1,2}$, CAO Guang-chao ${ }^{1,2}$, YANG Yu-fan ${ }^{1,2}$, \\ LAN Yao ${ }^{1,2}$, JI Yu-tong ${ }^{1,2}$, LI Hua-fei ${ }^{1,2}$ \\ (1. College of Geographical Sciences, Qinghai Normal University, Xining 810008, China; 2. Qinghai Provincial \\ Key Laboratory of Physical Geography and Environmental Processes, Xining 810008, China)
}

\begin{abstract}
Hydrogen and oxygen stable isotope technology is an effective method to study the surface water-groundwater interaction. Based on the hydrogen and oxygen isotope component $\left(\delta \mathrm{D}\right.$ and $\delta^{18} \mathrm{O}$ ) of precipitation, river water and groundwater collected in the Shaliu River Basin of Qinghai Lake during ablation period, rainy period and freezing period in 2018, the paper aims to clarify the spatio-temporal differences between $\delta \mathrm{D}$ and $\delta^{18} \mathrm{O}$ values of surface water and groundwater under the influence of precipitation. We use the two-component method to reveal and ensure the interaction between surface water and groundwater of alpine steppe zone and alpine meadow zone in three periods. Results show that, the impact of precipitation on surface water and groundwater is different in space and time. Stable isotopic response of surface water and groundwater to precipitation on the time is the strongest in ablation period and the weakest in freezing period. And the stable isotopic response of surface water and groundwater to precipitation in alpine meadow zone is stronger than that in alpine steppe zone. In alpine meadow and alpine steppe zones of ablation period and alpine steppe zone of freezing period, surface water recharges groundwater, and the ratio is $80.65 \%, 93.36 \%$ and $89.44 \%$, respectively. In alpine meadow and alpine steppe zones of ablation period and alpine meadow zone of freezing period, groundwater recharges surface water, and the ratio is $44.50 \%, 74.85 \%$ and $88.58 \%$, respectively. Thus, this study provides a scientific basis for the optimization, allocation and management of water resources.
\end{abstract}

Keywords: Qinghai Lake; Shaliu River Basin; stable isotopes of hydrogen and oxygen; surface water; groundwater; interaction 